\title{
Using a decadal diatom sediment trap record to unravel seasonal processes important for the formation of the sedimentary diatom signal
}

\author{
Dominique Béatrice Maier • Veronika Gälman • Ingemar Renberg • \\ Christian Bigler
}

Received: 31 July 2017 / Accepted: 17 January 2018/Published online: 15 February 2018

(C) The Author(s) 2018. This article is an open access publication

\begin{abstract}
Sediment trap studies and high frequency monitoring are of great importance to develop a deeper understanding of how seasonal environmental processes are imprinted in sediment signal formation. We collected whole year diatom assemblages from 2002 to 2014 with a sequential sediment trap from a varved boreal lake (Nylandssjön, Sweden) together with environmental and limnological parameters, and compared them with the corresponding diatom record of the annual laminated sediment. Our data set indicates a large year-to-year variability of diatom succession and abundance patterns, which is well reflected in the varved sediments. Specifically, Cyclotella glomerata dominated the annual sediment trap record (as well as in the corresponding sediment varves) in years with warmer air temperatures in March/April, and Asterionella formosa dominated the annual sediment assemblages as a consequence of years characterized by
\end{abstract}

D. B. Maier $(\bowtie) \cdot$ I. Renberg · C. Bigler

Department of Ecology and Environmental Science, Umeå University, 90187 Umeå, Sweden

e-mail: dominique.b.maier@gmail.com

I. Renberg

e-mail: ingemar.renberg@umu.se

C. Bigler

e-mail: christian.bigler@umu.se

\section{Gälman}

Diatoma miljöundersökningar, Flakaskärsvägen 28,

90582 Umeå, Sweden

e-mail: veronika.diatoma@telia.com higher runoff before lake over-turn. Years succeeding forest clearance in the lake catchment showed marked increase in diatom and sediment flux. The DCA scores of the yearly diatom trap assemblages clearly resemble the lake's thermal structure, which indicates that the relative abundance of major taxa seems primarily controlled by the timing of seasonal environmental events, such as above-average winter air temperature and/or autumn runoff and the current thermal structure of the lake. The high seasonal variability between environmental drivers in combination with the physical limnology leaves us with several possible scenarios leading to either an A. formosa versus $C$. glomerata dominated annual diatom sediment signal. With this study we highlight that short-term environmental events and seasonal limnological conditions are of major importance for interpreting annual sediment signals.

Keywords Annual diatom flux - Sequential sediment trap · Varved lake sediments - Seasonal air temperature $\cdot$ Discharge $\cdot$ Catchment

\section{Introduction}

Lake sediment proxies, particularly diatoms (Renberg et al. 1993; Battarbee 2000), are important records for the reconstruction of climate-induced changes on lake ecosystems (Smol et al. 2005), but the effects of 
seasonal processes on the formation of their sediment signals is rarely considered (Simola 1977; Lotter and Bigler 2000; Zahrer et al. 2013; Kienel et al. 2017). Understanding the consequences of changes in climate in the fall-spring months for lake biological processes is critical, however, because climate is projected to change most significantly in these seasons in the future in many locations at northern latitudes, including Scandinavia (Vautard et al. 2014). To develop a better understanding of how e.g. complex indirect atmospheric processes are imprinted in a biological sediment record, sediment reconstructions need to be refined (Catalan et al. 2013). Not least is the predictive power of transfer functions limited, as Juggins (2013) pointed out, as processes involved in the formation of biological lake sediment signals are not fully understood. The need for a better mechanistic understanding of diatom ecology and biology for past environmental reconstructions has been suggested repeatedly but rarely addressed, despite the application of increasingly advanced statistical tools (Haworth 1980; DeNicola 1986; Bradbury 1988; Rautio et al. 2000).

Capturing the effects of seasonal processes on sediment archives is complicated because the collection of data during the ice covered period and transitional seasons is logistically challenging. While field and laboratory studies provide critical insights into how specific seasonal processes are functioning over experimental timescales (up to a few years; e.g. Salmi and Salonen 2016), lake ecosystems are controlled by complex interactions among lake properties, catchment characteristics, climate conditions, and human activity which play out over longer timescales. Therefore, long time series are needed to understand how information from these various processes is integrated in sediment archives.

Seasonality has been a central theme in phytoplankton ecology for decades (Sommer et al. 1986; Sommer et al. 2012), and classical understanding of seasonality has informed the interpretation of sediment diatom records in previous studies, particularly as it relates to lake mixing depth (Saros et al. 2012, 2016; Boeff et al. 2016). However, recent studies highlight the variability of seasonal patterns in different lake types (Brentrup et al. 2016), and more and more studies have focused on the impact of winter processes on lake ecosystems (Salonen et al. 2009; Hampton et al. 2015, 2017; Contosta et al. 2017). Many of these studies demonstrate that a large fraction of annual production can occur during winter and early spring (Hampton et al. 2017). The importance of under-ice production may also be changing as climate warms (Contosta et al. 2017). A recent study has not only reported retreating ice-cover under increasing global temperatures, but also that algal growth under thinning ice has been underestimated, a mechanism that can have a major influence on annual productivity and even propagate to the entire food web of lakes and oceans (Horvat et al. 2017). The timing of snow melt in relation to ice-break up also affects the horizontal and vertical distribution of solutes and nutrients and their availability to primary producers (Cortés et al. 2017). Furthermore, shifts in seasonal dynamics have a strong effect on transitions and lags from ice-covered to ice-free conditions and vice versa (Contosta et al. 2017), with implications for the timing and strength of the thermal mixing in relation to the onset of algal spring blooms.

In paleolimnology as in limnology, it has often been assumed that the winter season is rather unproductive in contrast to the ice-free season. Based on this assumption, annual or summer mean air temperature seemed to be a reliable predictor for detecting changes in lake ecosystems (Smol et al. 2005). However, with the increasing recognition of the importance of winter and spring processes for lake productivity, an improved understanding of how environmental and ecological processes that occur at sub-annual timescales leave an imprint in the sediments is crucial. Several previous paleolimnological studies have suggested the possible importance of spring processes for the development of sediment records (Simola 1977; Lotter and Bigler 2000; Zahrer et al. 2013; Kienel et al. 2017). For example, the relationship between temperature, precipitation and floods remains poorly constrained, as Amann et al. (2015) concluded based on a varved sediment sequence from the western Alps.

Small Cyclotella taxa have been identified as a widespread element of the diatom assemblages in alpine, boreal and arctic lakes that are sensitive to shifts in temperature and ice-cover duration (Smol 1988; Lotter and Bigler 2000; Sorvari et al. 2002). However, patterns of change in Cyclotella taxa are not synchronous or unidirectional across or within regions, raising the question of how to interpret these widespread changes in diatom community structure (Saros and Anderson 2015). Mixing depth has been identified as one important variable controlling 
Cyclotella taxa (Boeff et al. 2016), even though the actual mechanism could not be fully revealed and seems to vary over regions and systems (Saros and Anderson 2015). Larger-celled diatom species are known to thrive under well mixed conditions (Round et al. 1990). Small-celled centric diatoms were originally described as "summer diatoms" because their growth benefits from more stable water columns (Hutchinson 1967); however stable water columns with high light availability may also be present in under ice surface layers (Maier et al. unpublished data).

Given the recent developments in winter limnology and the projected impact of climate change on climate during the fall, winter and spring months, there is a strong need to understand how seasonal environmental drivers affect lake ecosystems directly and indirectly, and how these signals are deposited and buried in the sediment record. In this study, we present diatom analyses from sequential sediment trap records with a resolution of 5-20 days per sample, and corresponding diatom records from the annually laminated sediments of a boreal lake, covering the period from 2002 to 2014. We describe the observed diatom fluxes and assemblage changes in the context of corresponding environmental parameters (air temperature, precipitation, discharge, length of ice-cover) and physical water-column parameters (depth of the mixed layer). The aims of this study were to assess (1) the interannual and sub-annual patterns of diatom fluxes and assemblage composition changes, (2) how these changes are associated with environmental parameters or correspond with drivers, and (3) the extent to which these patterns are reflected in the annually laminated sediments.

\section{Study site}

Lake Nylandssjön (Nordingrå, 62 $57^{\prime} \mathrm{N}, 18^{\circ} 17^{\prime} \mathrm{E}$, $35 \mathrm{~m}$ above sea level) is located at the northeastern coast of Sweden (Fig. 1a). It formed $\sim 4000$ years ago as a result of shore level displacement due to crustal uplift following the retreat of the Scandinavian ice sheet. The lake's catchment area of $0.95 \mathrm{~km}^{2}$ (Fig. 1b) alternates between silt and clay deposits at the north and northwestern side of the lake used as agricultural land (8\% of total catchment area) and forested hills of thinly covered bedrock around the southern basin and eastern shore. Between winter 1998 and 2013 parts of the forest within the catchment were cleared (Fig. 1c).

Since the beginning of cultural eutrophication about 100 years ago the sediment of the lake is annually laminated (i.e. varved) (Renberg 1981, 1986). A top view onto the frozen sediment retrieved by a freeze corer shows green-brownish sediment layers deposited during spring and summer which are clearly separated by black layers, which form under ice in winter as a result of slow-settling fine organic material (Gälman et al. 2008; Maier et al. 2013). A long ice-cover duration and stable anoxic conditions in the hypolimnion during most of the year allow the varve formation and prevent sediment mixing by bioturbation. Over the stratified period during the summer months, the oxygen free zone that can even reach up to $7 \mathrm{~m}$ below surface develops in the hypolimnion (Gälman et al. 2009).

The boreal headwater lake (surface area of $0.28 \mathrm{~km}^{2}$ ) has two main basins and a small outlet on the northern shore. The southern basin has a maximum depth of $14.3 \mathrm{~m}$ and the basin at the north end of the lake has a maximum depth of $17.5 \mathrm{~m}$, where sampling took place (Fig. 1b, c). The lake is dimictic with a residence time of $\sim 5$ years. Average secchi depth (3.2 m), TP $\left(18.3 \mu \mathrm{g} \mathrm{L}^{-1}\right)$, TN $\left(509 \mu \mathrm{g} \mathrm{L}^{-1}\right)$ and DOC (6.9 mg L ${ }^{-1}$ ) measured between 2012 and 2014 are typical for mesotrophic conditions (Maier et al. unpublished data).

\section{Materials and methods}

Environmental, catchment and physical limnology data

Gridded air temperature and precipitation data together with discharge from a stream in the lake's catchment for the years 2002-2014 were extracted from the Swedish Meteorological and Hydrological Institute (SMHI, http://luftwebb.smhi.se/) and monthly averages were calculated for each year. For evaluation purposes, monthly air temperature, precipitation and discharge data were transformed into anomalies.

Information about areas and dates for forest clearing (Fig. 1c) were downloaded from the Swedish Forest Agency (https://www.skogsstyrelsen.se/ skogsdataportalen). Forest clearing in the lake 

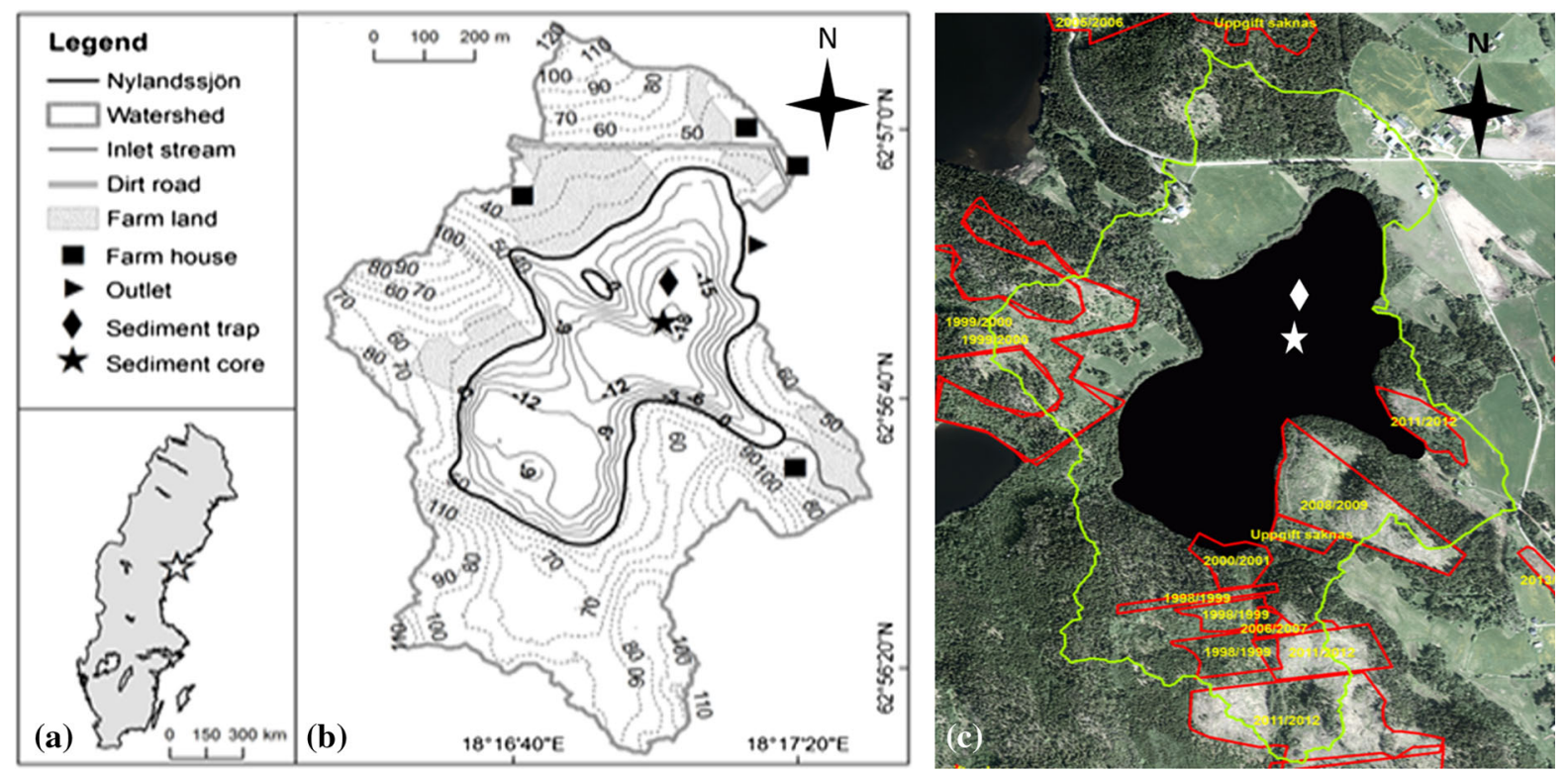

Fig. 1 a Location of study site Lake Nylandssjön (white star) on the North-east coast of Sweden (left) with $\mathbf{b}$ catchment, elevations (dotted contour lines) of forested hills (white) and arable fields (grey), the lake bathymetry (negative values) and the sediment trap at the deepest point (black diamond). c Areal

catchment took place in the late 1900s and early 2000s. During winter 2000/2001 and winter 2006/2007, no forestry activities were reported. Two considerably large areas in the catchment, located on the southern hills, were reported for clearance in winters 2008-2009 and 2011-2012 (Fig. 1c).

Over the period from 2002 to 2014 bi-weekly vertical temperature profiles were taken at $1 \mathrm{~m}$ intervals with a handheld sensor (YSI ProODO). The depth of the mixed layer $\left(\mathrm{Z}_{\mathrm{mix}}\right)$ was determined as the point of maximum rate of change between two consecutive depths (Carlson and Simpson 1996). Icecover duration was recorded during the bi-weekly winter sampling.

\section{Sequential sediment trap}

A sequential sediment trap (Technicap PPS 4/3) has been deployed in the north basin with since March 2002 at a depth of $14 \mathrm{~m}$ below the surface. The trap is moored (with a weight) on the lake bottom and held vertical by a steel wire connecting the trap with three buoys $2 \mathrm{~m}$ below the water surface. At the bottom of the trap funnel a motor rotates 12 sample containers, which were usually exchanged three times per year, in picture of Nylandssjön and its catchment (indicated as green line). Red areas indicate forest declared for clearance in the winter month of the respective years (indicated in yellow). (Color figure online)

February, May and September. The trap container rotation frequency was regulated to match expected seasonal sediment deposition patterns, with high frequencies during periods with high sedimentation rates and vice versa. From September to February the rotation frequency was low (20 days), increased until May to a maximum (5 days) and decreased between May and September (9 days).

\section{Sampling of varved sediments}

The sediment of Nylandssjön was sampled in March 2015 using a freeze corer (Renberg and Hansson 2010). The freeze core was stored frozen until individual varves were cut by hand with a scalpel from the sediment surface down to the surface of the black winter layer of the preceding year (Renberg 1981). For the comparison of annual diatom accumulation between sediment trap and sediment, so-called varve years were calculated (defined as $\sim$ of 1 year until 31 March in the following year). Each varve year approximately coincides with the distinct shift from the dark winter layer to the light spring layer in the sediment. 
Diatom analyses

For diatom analysis hydrogen peroxide was added to $5 \mathrm{mg}$ of freeze-dried sediment or 2-3 mg of freezedried sediment trap material and heated in a water bath to degrade the organic material and retain the diatom frustules (Battarbee et al. 2001). Before mounting on slides for identification and enumeration, microspheres were added as external markers to the diatom samples (Battarbee and Kneen 1982). Using a Zeiss Axioplan microscope, a minimum of 200 valves in each sample were counted based on standard diatom identification literature such as Krammer and LangeBertalot (1986-1991). We present the 12 most abundant diatom taxa together with the rest (summarized as 'Other taxa') of the sediment trap and the sediment record.

Statistical data analysis and interpolation

In this study, 45 trap series covering the period from March 2002 to May 2015 were analyzed. Out of the 540 rotations, 76 samples had to be excluded due to technical failures (malfunction of engine) or sampling errors (catching of fish; Table 1). For the years 2011-2014, all diatom sediment trap samples were counted, whereas for the other years (2002, 2003 and 2004 and 2008) every second sample was analyzed. To match the annual diatom flux in the sediment trap with the varved sediment record, missing samples were interpolated by calculating the average between the previous and following sample. Values for the winter samples of 2005, 2007 and 2008 were interpolated based on averaged winter values $\left(10,000\right.$ valves $\left.\mathrm{cm}^{-2} \mathrm{~d}^{-1}\right)$. Due to trap failure, the sediment trap data for the years 2006, 2009 and 2010 were incomplete to such a degree that they had to be excluded from the 13-year time-series.

To identify major ecological shifts in the diatom sediment trap flux a detrended correspondence analysis (DCA) was carried out using the CANOCO software (version 4.52; Ter Braak and Smilauer 2002). Monthly averages of DCA axis 1 and DCA axis 2 scores were calculated for each year and annual cycles of diatom community composition were visualized in DCA ordination space.

\section{Results}

Environmental, catchment and physical limnology data

Over the study period (2002-2014), monthly mean air temperatures $\left({ }^{\circ} \mathrm{C}\right)$ at Nylandssjön were below freezing point from December to March (minimum $-5{ }^{\circ} \mathrm{C}$ ). Maximum mean monthly air temperatures were recorded in July $\left(16^{\circ} \mathrm{C}\right)$. Average monthly precipitation $(\mathrm{mm})$ is highest from August to October. Monthly mean discharge $\left(\mathrm{m}^{3} \mathrm{~s}^{-1}\right)$ as an equivalent for catchment runoff reaches a maximum in April as a result of snowmelt, and a second peak of discharge was associated with the high precipitation mean in November. The environmental setting for an average year, including atmosphere (air temperature, precipitation), catchment (discharge), and in-lake processes ( $\mathrm{Z}_{\text {mix }}$, ice-cover duration) is summarized in Fig. 2.

The 12 years of lake monitoring showed that the ice-cover duration varied between 128 and 185 days, covering the period from November/December until April/May (Fig. 2). Thermal stratification of the lake showed a very consistent pattern over the study period. During the period with ice-cover, the water-column was stratified to a depth of $0.5-1 \mathrm{~m}$ below the icecover. Spring over-turn occurred during the period from the end of April to the beginning of May. Spring over-turn could take place already under the ice-cover, but also after ice break-up. Early spring over-turn (beginning of April) was measured in the years 2002, 2007 and 2012 and was directly followed by a gradual deepening of the thermocline over the ice-free period. The thermocline broke down by the end of September, followed by autumn over-turn occurring during the period from October and end of November (Fig. 2).

Timing of elevated winter month air temperature, discharge and spring over-turn

For our study period, March and April air temperatures were above average in 2002, 2003, 2007, 2011, 2012 and 2014 opposed to on-average/below-average in 2004, 2005, 2008 and 2013 (Fig. 3). Above-average late-winter air temperatures were in general not connected with a clear precipitation signal, but with above-average discharge before lake over-turn, when the lake was still ice-covered and the surface water layer under the ice still stratified (Figs. 2, 3). 
Table 1 List of years and samples excluded due to technical failures (malfunction of engine) or sampling errors (fish in sample container) together with number of days and percentage per year for each year of the time series between 2002 and 2012

\begin{tabular}{|c|c|c|c|}
\hline \multicolumn{2}{|c|}{ Years excluded due to technical errors } & Days missing & \multirow{2}{*}{$\begin{array}{l}\% \text { Missing per year } \\
50\end{array}$} \\
\hline 2006 & $2006-06-30$ to $2006-12-30$ & 183 & \\
\hline \multirow[t]{2}{*}{2009} & $2009-07-23$ to $2009-09-29$ & 68 & 69 \\
\hline & $2009-09-30$ to $2010-02-10$ & 133 & \\
\hline 2010 & $2010-06-05$ to $2010-09-21$ & 108 & 30 \\
\hline \multicolumn{2}{|c|}{ Years with periods of every second sample interpol. } & Days interpol. & $\%$ Interpol. per year \\
\hline \multicolumn{2}{|l|}{2002} & 147 & 41 \\
\hline \multicolumn{2}{|l|}{2003} & 104 & 30 \\
\hline \multicolumn{2}{|l|}{2004} & 201 & 57 \\
\hline \multicolumn{2}{|c|}{ Interpolated continuous winter periods } & Days interpol. & $\%$ Interpol. per year \\
\hline 2005 & $2005-02-15$ to $2005-04-01$ & 45 & 25 \\
\hline 2007 & $2007-12-06$ to $2008-03-03$ & 88 & 36 \\
\hline 2008 & $2008-03-04$ to $2008-04-23$ & 50 & 20 \\
\hline \multicolumn{2}{|c|}{ Samples excluded due to sampling errors } & Days interpol. & $\%$ Interpol. per year \\
\hline \multirow[t]{2}{*}{2013} & 2013-04-10 to $2013-04-15$ & 5 & 3 \\
\hline & $2013-05-05$ to $2013-05-10$ & 5 & \\
\hline \multirow[t]{4}{*}{2014} & $2014-05-17$ to $2014-05-22$ & 5 & 8 \\
\hline & $2014-05-22$ to $2014-05-28$ & 6 & \\
\hline & $2014-06-05$ to $2014-06-13$ & 8 & \\
\hline & $2014-08-06$ to $2014-08-15$ & 9 & \\
\hline
\end{tabular}

Winter 2007/2008 was an exception as winter discharge was high, but highest already in December and January, coinciding with a very early lake overturn, breaking up the stratified water layer under ice. A similar pattern occurred in 2007 when warm latewinter air temperatures were recorded, coinciding with an early discharge but also a very early lake overturn that took place when the lake was still icecovered.

In years with average or below-average late-winter air temperature (March and April), increased discharge was delayed (until April), and rather coincided with a water-column mixing than with a shallow under-ice stratification (2004, 2005, 2008 and 2013) (Fig. 3).

Timing of summer discharge, thermocline break up and autumn over-turn

Over the ice-free season, no obvious relation to air temperature was observed. Above-average precipitation mainly led to above-average discharge in August (2003, 2004, 2005, 2011, 2013), which co-occurred with the break-up of stratification or autumn lake overturn.

In 2008, higher precipitation occurred in October and above average discharge co-occurred with lake over-turn. In 2002 and 2007, precipitation and discharge were below-average for almost all of the ice-free season. In 2012, discharge was only aboveaverage in September and October and even later in 2014 (October and November) after the onset of lake over-turn (Fig. 3).

Integrated annual diatom and sediment fluxes in the sediment trap

For the period 2002-2008, the annual diatom fluxes in the sediment trap fluctuated from $8.30 \times 10^{6}$ valves $\mathrm{cm}^{-2} \mathrm{yr}^{-1}$ to $1.52 \times 10^{7}$ (Table 2; Fig. 4). For the period 2011-2014, the diatom fluxes were considerably higher, resulting in an average value of $3.75 \times 10^{7}$. The annual sediment fluxes followed largely the same trend as the diatom flux in the trap (Table 2; Fig. 4). Over the period 2002-2008, the annual sediment flux was highest in 2002 


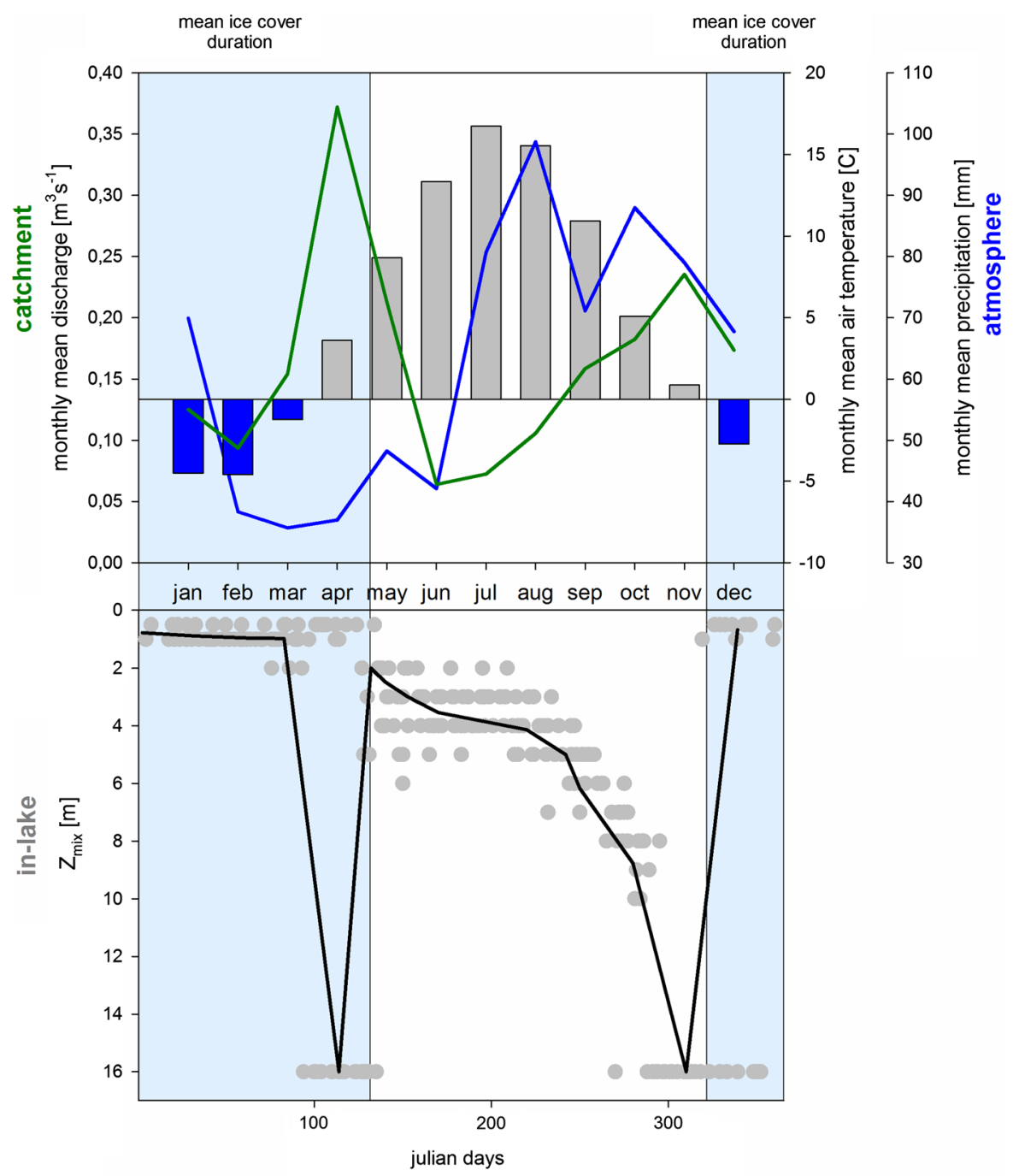

Fig. 2 Monthly mean (2000-2015) of atmospheric (air temperature, precipitation), catchment (discharge) and in-lake processes $\left(Z_{\text {mix }}\right.$, ice-cover duration). The $Z_{\text {mix }}$ from the bi-

$\left(2.3 \times 10^{7} \mathrm{mg} \mathrm{m}^{-2} \mathrm{yr}^{-1}\right)$, and always above $2.0 \times 10^{7}$ during the years 2011-2014 (maximum 2013 with $3.3 \times 10^{7}$, Table 2; Fig. 4).

Sub-annual patterns of diatom and sediment fluxes in the sediment trap

Besides the great interannual differences in diatom and sediment flux, the diatom flux patterns were similar over the monitored years. The general subannual pattern for the diatom sediment flux consisted of two peaks (Fig. 4). A first major flux peak occured in June, with a gradual build-up over May and decline weekly measurements (grey dots) is shown together with monthly mean over the study period. (Color figure online)

in July. A second, in general lower peak compared to the spring flux, occurs at end of August or beginning of September.

Exceptions are the years 2008, 2011 and 2013, where the second flux peak was higher than the first. The later the second peak occured, the higher it was (i.e., in 2011 and 2013). A third relatively abrupt diatom flux increase could occur between end of October and end of November (highest in 2008, Fig. 4).

The sub-annual diatom flux patterns and the sediment flux patterns in the sediment trap were very similar. The sediment flux during winter was 


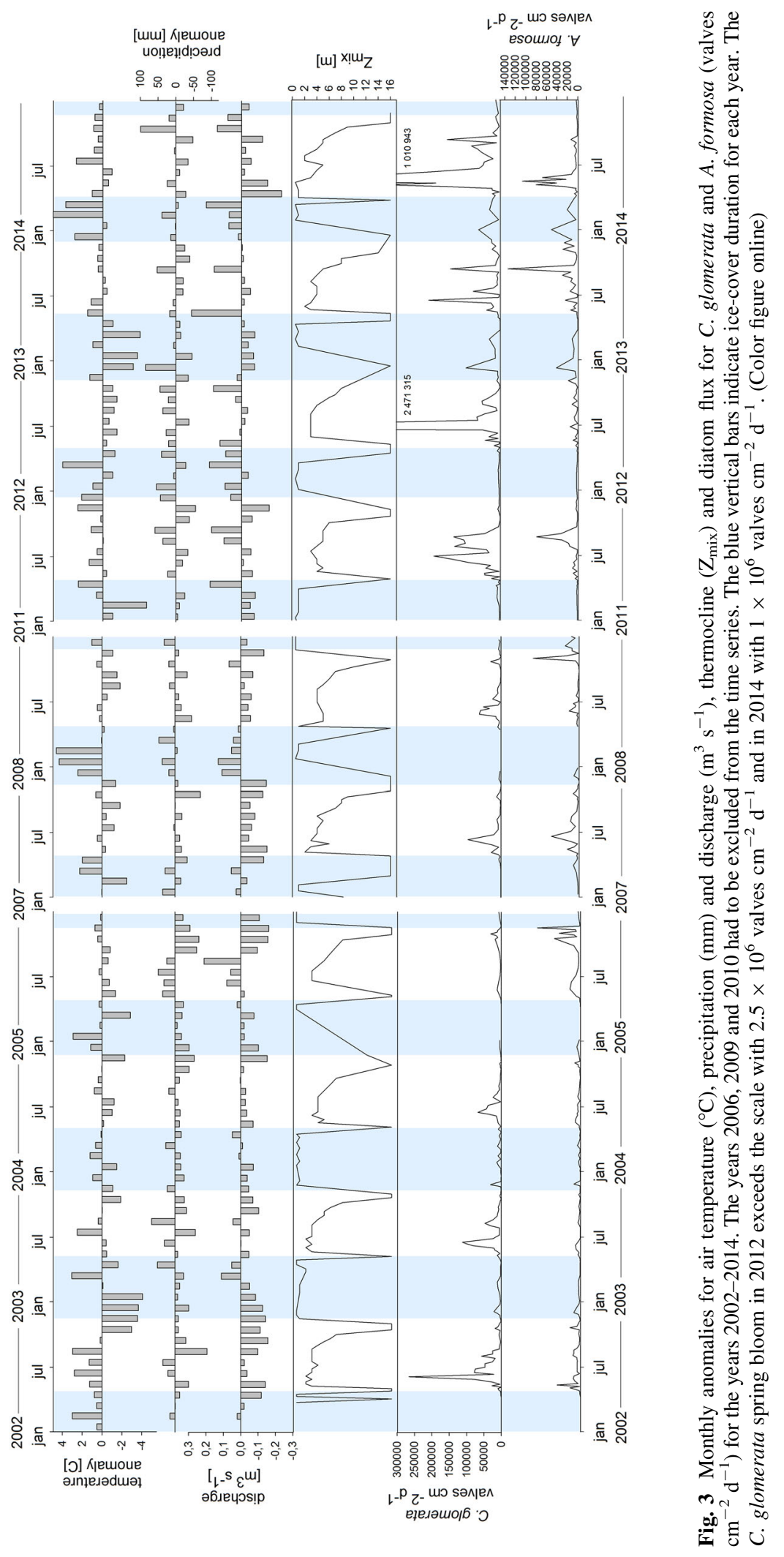


continuous but low. Two flux peaks also characterized the sub-annual pattern for sediment flux, with the spring peak in June in general exceeding the autumn peak in late August (exception 2011). In all years, major spring and autumn flux peaks are preceded by an increased material flux in May (most pronounced in 2012) and followed by one or two peaks in November and/or December with varying magnitudes.

Exceptions were 2002 and 2011, when the initial sediment flux peak in May was higher than the sediment flux during the major diatom peak in June. In 2003, the highest sediment flux occurred by the end of November. The December sediment trap flux was higher than August flux in 2003, 2005, 2007 and 2012.

Comparison of the diatom record in the sediment trap with varved sediments

The integrated annual diatom flux in the sediment trap and the diatom sediment flux were in the same order of magnitude for all years (Table 2). In order to evaluate that no major bloom was missed due to interpolation of missing data points in the sediment trap, we compared annual accumulation patterns (in percent) for the most abundant diatom taxa between sediment trap and sediment prior to further interpretation of the dataset. The comparison showed that the relative abundance of taxa in general matched well. However, among all years, minimal accordance was recorded for the year 2004, probably due to the fact that every second sample and all winter samples had to be based on interpolation (Fig. 4).

Twelve major diatom taxa were selected, which represented at least $70 \%$ of the assemblage in the sediment trap and $65 \%$ of the sediment record (Fig. 5). The overall annual pattern of the relative abundance of each of the 12 major taxa is in very good accordance between the sediment trap and the varved sediment (Fig. 5). The taxa Cyclotella glomerata and Asterionella formosa were the two most abundant taxa in all years over the sampling period. C. glomerata contributed $21-69 \%$ to the annual diatom record in the sediment trap, and $14-72 \%$ in the sediment, whereas A. formosa contributed $6-55$ and $4-31 \%$, respectively (Fig. 5).

In the sediment, in nine out of 13 years (2002, 2003, 2007, 2009-2014) the relative abundance of C. glomerata exceeded the abundance of A. formosa. In 2007, the relative abundance of both taxa was rather
Fig. 4 Annual sediment flux $\left(\mathrm{mg} \mathrm{m}^{-2} \mathrm{~d}^{-1}\right.$, red) and diatom flux (valves $\mathrm{cm}^{-2} \mathrm{~d}^{-1}$, green counted, grey interpolated) for the years 2002-2005, 2007-2008 and 2011-2014. Due to interannual differences scales for the years 2012-2014 differ for sediment and diatom fluxes from the previous years (indicated with asterisk). (Color figure online)

similar (38\% of C. glomerata and $33 \%$ of A. formosa). In the remaining 4 years (2004-2006 and 2008), the relative abundance of $A$. formosa exceeded the relative abundance of $C$. glomerata (Fig. 5). In the sediment trap, the years 2006, 2009 and 2010 could not be analyzed, but relative abundances in the sediment trap for $C$. glomerata and A. formosa were in agreement with the sediment for 2002 and 2003, 2005 and 2011-2014. The interpolation of taxa was least reliable for 2004, and possibly an autumn bloom of $A$. formosa was not covered by the sediment trap counts (Fig. 5).

Comparison of diatom assemblages across years

The DCA scores on axis $1(\lambda=0.123)$ and axis 2 $(\lambda=0.050)$ of the diatom trap assemblages across all years follow a clockwise circular pattern following the seasons (Fig. 6) but show a high inter-annual variability (Fig. 7).

The DCA axis 1 scores show a close relation with the changes and characteristics in the thermal structure during each year, while DCA axis 2 scores mainly deviate during stratified periods from DCA axis 1 scores (Fig. 8). These differences indicate that DCA axis 1 scores mainly reflect changes in C. glomerata within the diatom assemblage in accordance with thermal structure and DCA axis 2 the dominance of $A$. formosa within the diatom assemblage (Fig. 3).

Sub-annual patterns of diatom flux of two major taxa

Over the ten monitored years, the two major diatom taxa C. glomerata and A. formosa exhibited two different seasonal patterns in the sub-annual sediment trap record, however, with varying flux magnitudes (Fig. 3). The first pattern was characterized by a major C. glomerata spring (April/May) flux peak, accompanied by a subsequent $A$. formosa bloom in June with no further comparable bloom entering the trap in the 


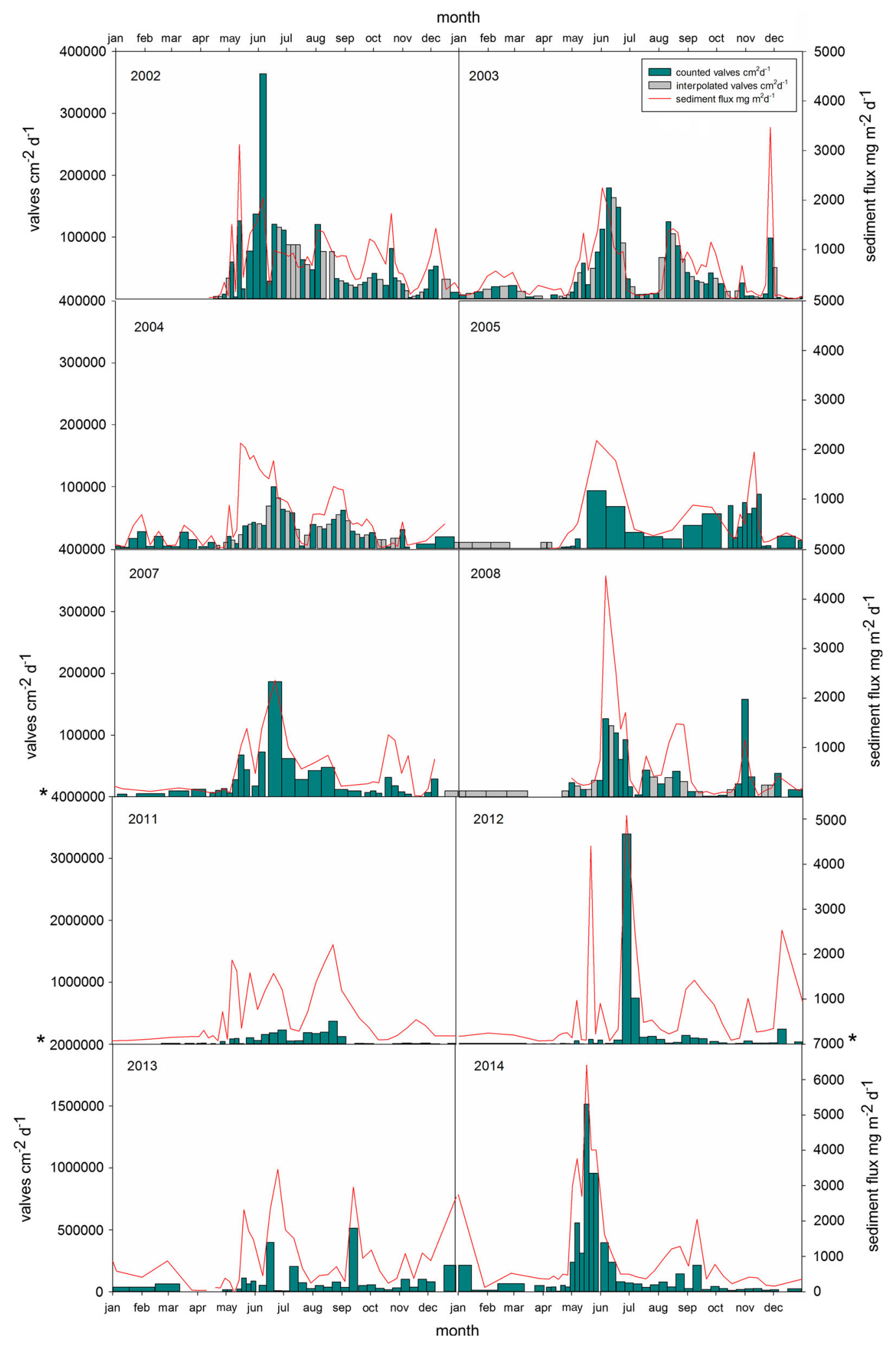


Table 2 Comparison of annual diatom flux (valve $\mathrm{cm}^{-2} \mathrm{yr}^{-1}$ ) for the varved years 2002-2014 between varved sediment and sequential sediment trap and annual trap sediment flux $\left(\mathrm{mg} \mathrm{m}^{-2} \mathrm{yr}^{-1}\right)$

\begin{tabular}{llll}
\hline Years & $\begin{array}{l}\text { Diatom flux sediment trap } \\
\left(\text { valves cm } \mathrm{yr}^{-1}\right)\end{array}$ & $\begin{array}{l}\text { Sediment flux sediment trap } \\
\left(\mathrm{mg} \mathrm{m}^{-2} \mathrm{yr}^{-1}\right)\end{array}$ & $\begin{array}{l}\text { Diatom flux sediment } \\
\left(\mathrm{valves} \mathrm{cm}^{-2} \mathrm{yr}^{-1}\right)\end{array}$ \\
\hline 2002 & $1.52 \times 10^{7}$ & $2.3 \times 10^{7}$ & $7.37 \times 10^{7}$ \\
2003 & $1.12 \times 10^{7}$ & $1.8 \times 10^{7}$ & $1.08 \times 10^{8}$ \\
2004 & $8.30 \times 10^{6}$ & $1.6 \times 10^{7}$ & $7.91 \times 10^{7}$ \\
2005 & $1.10 \times 10^{7}$ & $2.0 \times 10^{7}$ & $2.06 \times 10^{8}$ \\
2006 & n.a. & n.a. & $8.32 \times 10^{7}$ \\
2007 & $9.22 \times 10^{6}$ & $1.6 \times 10^{7}$ & $2.62 \times 10^{8}$ \\
2008 & $1.03 \times 10^{7}$ & $1.8 \times 10^{7}$ & $8.67 \times 10^{7}$ \\
2009 & n.a. & $\mathrm{n} . \mathrm{a}$. & $6.31 \times 10^{7}$ \\
2010 & n.a. & $\mathrm{n} . \mathrm{a}$. & $4.93 \times 10^{7}$ \\
2011 & $1.97 \times 10^{7}$ & $2.0 \times 10^{7}$ & $8.01 \times 10^{7}$ \\
2012 & $5.92 \times 10^{7}$ & $2.7 \times 10^{7}$ & $3.98 \times 10^{7}$ \\
2013 & $2.84 \times 10^{7}$ & $3.3 \times 10^{7}$ & $7.52 \times 10^{7}$ \\
2014 & $4.28 \times 10^{7}$ & $2.8 \times 10^{7}$ & $4.98 \times 10^{7}$ \\
\hline
\end{tabular}

The years 2006, 2009 and 2010 had to be excluded due to lack of data (indicated as not assessed, n.a.)

remainder of the same year $(2002,2003,2004,2007)$. The diatom flux in 2012 and 2014 also followed this pattern, characterized by a spring bloom dominated by C. glomerata, but flux values (valves and sediment) were high over the entire sampling period (between $1 \times 10^{6}$ and $3 \times 10^{6}$; Figs. 3, 4). Therefore, this pattern was characterized as a variation of the first pattern. The second pattern was characterized by an autumn (October/November) bloom of A. formosa with either no $C$. glomerata bloom occurring in the same year (2005) or accompanied with a $C$. glomerata spring and autumn bloom (2008). Variations of the second pattern were the years 2011 and 2013, where an A. formosa bloom was recorded, but already in September (Fig. 3).

\section{Discussion}

To be able to fully interpret paleolimnological records, a detailed understanding of the limnological conditions in which different proxy organisms develop, the timing of how these organisms are distributed throughout the annual cycle, and the mechanisms by which these organisms are deposited and buried in the sediment archives is fundamental. Whereas calibration based on a space-for-time substitution (so-called calibration-set approach) has been a frequently applied approach within paleolimnology during recent decades (Weckström et al. 1997; Lotter et al. 1997), the resulting statistical relationships may not accurately capture the mechanisms driving sediment signal formation. Recently, more and more focus has been directed towards understanding processes and mechanisms in single lakes (Kienel et al. 2017; Bonk et al. 2015). In this context, sediment traps are considered to be a valuable tool to understand taphonomic processes in lakes, often operated in combination with monitoring of limnological variables (Ojala et al. 2014). However, many sediment trap data-sets are restricted to very few years and only during the open-water period, and thus fail to capture the entire range of interannual and sub-annual variations. In this perspective, our decadal-scale record in Nylandssjön is very valuable, both in demonstrating that the sediment trap accurately represented the formation of annual signals in the varved sediment of Nylandssjön, and in highlighting the wide range and extreme variability of seasonal contributions to annual sediment diatom archives. Despite this extreme variability, we were able to observe distinct seasonal patterns of sedimenting diatom communities (Figs. 6, 7), and we were able to loosely classify years which exhibited distinct deposition patterns for dominant diatom species ( $A$. formosa and $C$. glomerata). The patterns were likely 

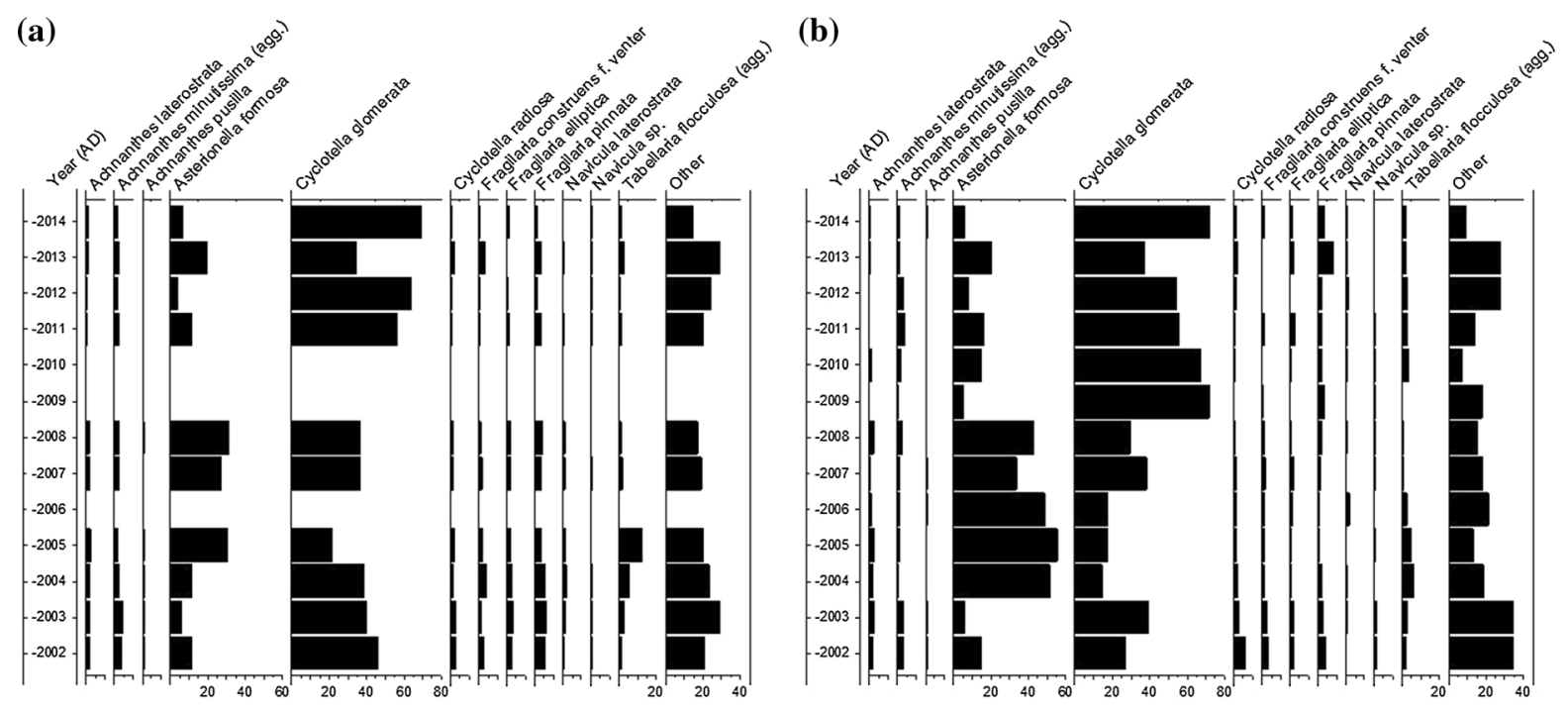

Fig. 5 Relative abundance (\%) of the 12 most abundant diatom taxa in Nylandssjön from 2002 to 2014 in a the sediment trap and b the varved sediment

driven by the timing of physical mixing processes in relation to periods conducive to diatom growth.

Annual diatom and sediment flux patterns

It is generally acknowledged that the funnel of sequential sediment traps results in an underestimation of the sediment and diatom fluxes (Ryves et al. 2003). Accordingly, our data-set indicates that the sediment fluxes calculated in the sediment are generally higher than the fluxes in the sediment trap. Overall, the sediment flux patterns compare rather well with the diatom flux patterns, indicating that diatoms are representing a major part of the deposited sediment (Fig. 5). Despite overall subtle changes in atmospheric and catchment conditions, the inter-annual variations in diatom and sediment fluxes between different years are substantial. For example, some years show a pronounced spring peak (2002, 2012 and 2014), some a pronounced fall peak $(2003,2008)$, some relatively constant (2004) and some rather low sediment and diatom fluxes (Fig. 4). This high inter-annual variability has also been recorded in other sediment trap studies and in varying environmental settings (Thackeray et al. 2008; Kirilova et al. 2011; Kienel et al. 2017).

After 2011, annual sediment trap fluxes were highest for the entire period of sediment trap deployment. High spring sediment trap fluxes $(2002,2008$

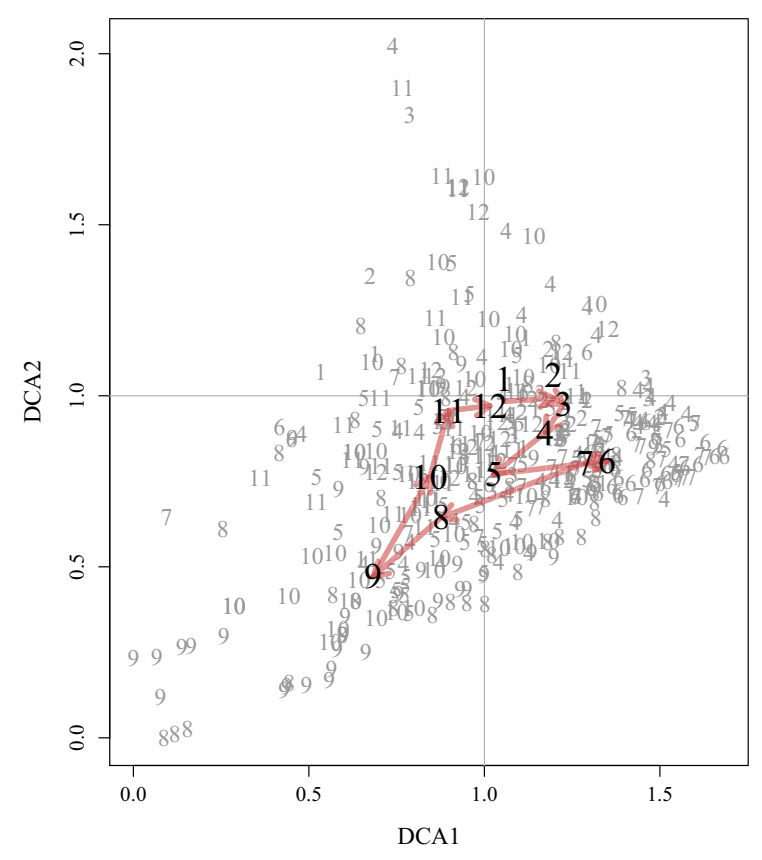

Fig. 6 DCA ordination showing data points for all 10 years of sequential sediment trap sampling labeled by month (1-12). Monthly means are shown with large numbers. Arrows show the average annual cycle in the ordination space. (Color figure online)

and 2012-2014) were presumably affected to some extent by forest clearance within the catchment of Nylandssjön. The effect of forest management is corroborated by scattered measurements of carbon 

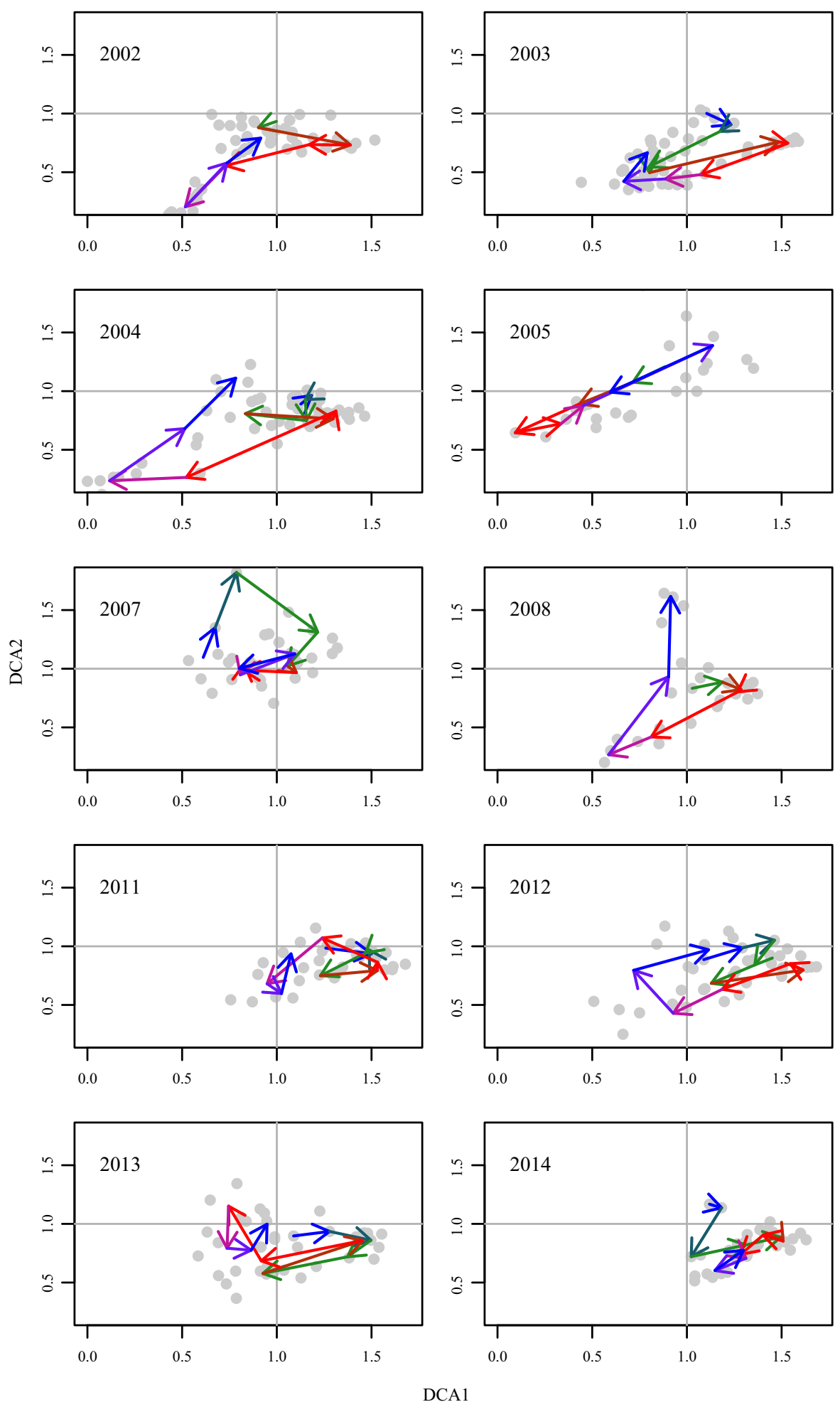

Fig. 7 DCA ordination for each of the 10 years in the trap time series. Arrows show the annual cycle in the ordination space. Blue colors indicated the ice covered month from December to
February, green the spring month from March to May, red the summer month from June to August and purple the autumn month from September to November. (Color figure online) 
Fig. 8 DCA axis 1 scores (filled circles) and axis 2 scores (open circles) and $Z_{\text {(mix) }}$ for each of the 10 years in the trap time series. DCA axis 1 scores increase during spring stratification under ice and after spring turn-over and decrease during spring turnover and deepening of stratification. DCA axis 2 scores mainly follow the same pattern with major exceptions in 2004, 2005, 2007, 2008 and 2013 in the trap samples. (Color figure online)
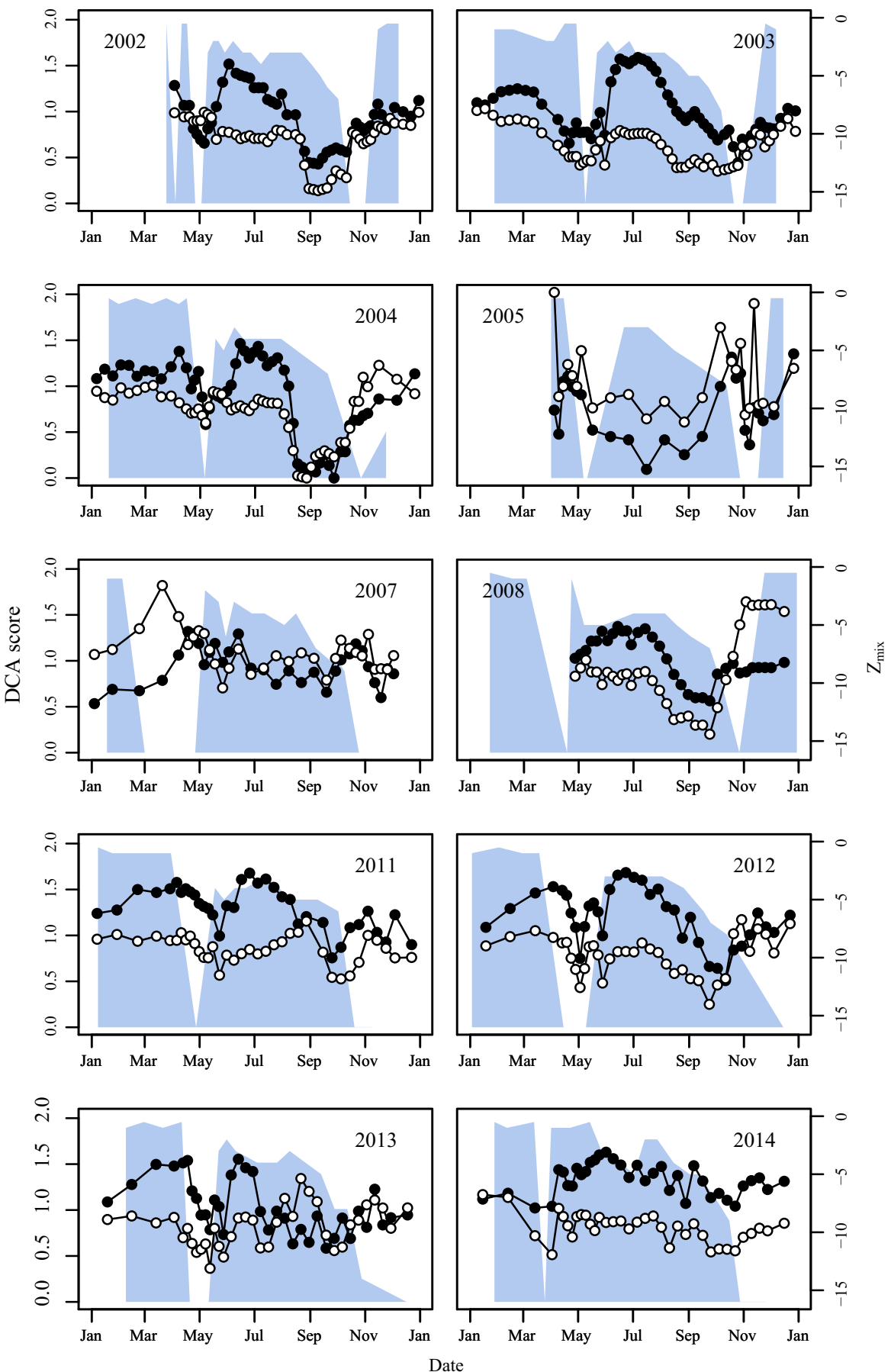

(C) and nitrogen (N) ratios from sediment trap material from Nylandssjön, which indicate input of allochthonous material over a very short period just before or right after ice break-up (data not shown). Forest clearing is widely understood to impact sedimentation rates in lakes (Anderson et al. 1995). There was no forest clearance reported within the catchment for the period after winter 2000/2001 until winter 2006/2007, when a small area in the catchment was cleared. As a consequence, the spring sediment 
flux recorded in the sediment trap was relatively low during the period 2003-2007 (Fig. 4). Relatively large proportions of the catchment were subjected to forest clearance in winter 2008/2009 and 2011/2012 (Fig. 1c), resulting in elevated spring sediment fluxes for 2012-2014 (flux data for 2009 and 2010 are missing).

\section{Seasonal cycles}

Despite the high inter-annual variability observed in sedimentation rates (Fig. 4), the community composition, as represented in DCA ordination space, showed a coherent seasonal pattern (Fig. 6), suggesting that species succession patterns were consistent despite the fact that sedimentation rates could vary by almost an order of magnitude in some years. While interpretation of the environmental correlates of the DCA ordination axes is difficult without a more comprehensive limnological dataset containing more potential drivers, mixing depth clearly played a role in structuring the variation of the sedimenting diatom composition (Fig. 8). The seasonal change in mixing depth corresponds most clearly to DCA axis 1 , which shows a clear trajectory from right to left as mixing depth deepens between June and September (Fig. 6). This corresponds to the shift from $C$. glomerata dominance in the spring to A. formosa dominance in the autumn over-turn. Changes in mixing depth previously been suggested as a general possible mechanism to be important forchanges in diatom community composition in paleolimnological studies (Smol et al. 2005; Sivarajah et al. 2016). Saros et al. (2012, 2016) showed with experimental work a success of Cyclotella species with shallower mixing depth.

Despite the relatively consistent annual cycle present across all years, individual years showed variable seasonal patterns of diatom growth in the ordination space (Fig. 7). Generally speaking, the seasonal variation along axis 1 was preserved (from right to left during the stratified period, and from left to right during the winter), but different years showed variable degrees of variation along axis 2. The variation in annual patterns is likely the result of differences in the relative abundance of the two most abundant taxa in the sediment record, A. formosa and C. glomerata. The interannual variability observed in the seasonal dynamics of these species (as well as the entire diatom community) is likely due to interactions between environmental drivers affecting diatom growth and environmental drivers affecting the delivery of diatoms to the sediment. This variability also suggests that caution should be exercised when interpreting the results of previous studies, which have made reconstructions of paleolimnological diatom records using data from only one or several growing seasons (Köster and Pienitz 2005). Diatom abundances are not linear functions of simple environmental parameters, and we find within 10 years several scenarios which may explain why an annual diatom record can be dominated by $C$. glomerata or $A$. formosa.

Sub-annual flux patterns of two major diatom taxa in relation to environmental variables

Despite the considerable inter-annual variability, we identified two major seasonal patterns in the sediment trap related to the two most abundant taxa. The first pattern is characterized by a $C$. glomerata dominated spring bloom, and the second by an A. formosadominated autumn bloom. We hypothesize that the build-up and the intensity of a $C$. glomerata-dominated spring bloom was mainly driven by relatively high winter air temperature and the associated early runoff, transporting available nutrients to the lake. This is supported by the high late-winter temperatures in at least some months observed during the years with strong C. glomerata spring blooms (2002, 2003, 2004, 2007, 2008, 2011, 2012, 2014; Fig. 3). During these warm late-winter periods, stratified conditions in the surface water under the ice, increased light availability due to reduced snowpack and thinning ice, and excess nutrient concentrations likely favored the growth of phytoplankton (Salmi and Salonen 2016), including C. glomerata, which is known to favor conditions of shallow stratification and high light availability (Hutchinson 1967; Saros et al. 2012). These conditions are usually observed during early shallow spring stratification after over-turn (Wiltse et al. 2016), but also occur in under-ice surface water layers which are rarely sampled. Early spring runoff may also increase nutrient availability under ice through the lateral dispersion of solutes into the stratified under ice surface layer, in contrast to a flush through the system within a more rapid spring flood (Cortés et al. 2017; Jeppesen et al. 2009). Other recent studies have also 
identified a relationship between warm early-spring conditions and the increased prevalence of C. glomerata (Wiltse et al. 2016) although the mechanisms hypothesized to explain the observed trends were somewhat incomplete, in part because continuous measurements were not made throughout the winter period.

In general, we hypothesize that during warm winters, the interplay of ice thinning, runoff due to snow melt and reduced snow cover on the ice, increases the probability for (1) a strong $C$. glomerata bloom, which (2) may take place already before spring lake over-turn (Maier et al. unpublished data). Following these under-ice blooms, subsequent spring over-turn is likely to deliver large numbers of diatoms to lake sediments, although there is likely to be a delay between over-turn and the accumulation of settling diatom remains. This strong spring $C$. glomerata signal can also be reinforced by years with prolonged periods of shallow thermal stratification after spring over-turn (e.g. 2008; Fig. 3); however, C. glomerata accumulation during this later period is never as great as the initial pulse following warm winters. As most of the studies do not include the pre-spring conditions as one of the major contributing processes, they often attribute $C$. glomerata growth to the mixing period, rather than to the stable, light-saturated surface layer (under ice) conditions which preceded it. This potential oversight may explain the controversy regarding potential drivers of trends in C. glomerata (Saros and Anderson 2015; Wiltse et al. 2016; Ruehland et al. 2008). This controversy centers around the debate between the relative importance of earlier mixing and shorter shallow spring stratification, but neglects the fact that the bloom is an effect of a process which is not necessarily synchronous but occurred with a time lag before the bloom is measured.

The second observed seasonal pattern was characterized by domination of the annual sediment signal by deposition of $A$. formosa during the autumn. Years with this pattern (2004-2008) were driven by high discharge in autumn, which enters the water-column when it is still stratified. This discharge likely provided nutrients which fueled A. formosa blooms, which were subsequently transported into the sediment trap when the lake turned over. This mechanism explains the sudden autumn A. formosa peak coinciding with autumn lake over-turn (2005, 2008 and 2013). A. formosa dominated the sediment signal in 4 years, however in each of these years the temporal patterns of diatom deposition to the sediments were very different, and were driven by different physical environmental drivers (Fig. 3). A. formosa can solely bloom in autumn or accompany a spring bloom of $C$. glomerata. In the latter case its contribution to the annual relative abundance is much less of the sediment record. In general A. formosa is characterized also to bloom in spring throughout the summer with declining numbers (Reynolds et al. 1982). The variability of the seasonal patterns observed for $A$. formosa formation is consistent with previous literature on A. formosa dynamics, which suggest that $A$. formosa can be driven either by nutrient availability (Saros et al. 2005), climate conditions (Thackeray et al. 2008), or lake mixing (Sivarajah et al. 2016). The results of this study confirm that $A$. formosa is dominant during mixed conditions (Reynolds et al. 2002) but may be lacking the nutrients in years when early Cyclotella blooms remove these nutrients; as a result, they can only increase in numbers during autumn when nutrient enriched discharge is delivered during favourable mixing conditions. Hence, making general assumptions regarding changes in either thermal structure or nutrients alone is not advisable.

Consequences for interpreting the sedimentary diatom record

The results of this study suggest that there is not yet a clear, single mechanism which can explain the observed inter-annual variation in sediment diatom communities, making it difficult to isolate a single proxy for past environmental conditions. However, there was a clear seasonal pattern to the sedimenting diatom composition (Fig. 6), suggesting that further studies may be able to extract information regarding the seasonality of diatom productivity from sediment archives, particularly relating to the relative abundances of $A$. formosa and C. glomerata. Care should be taken when drawing specific conclusions regarding seasonality, because similar sediment signals could be produced in years with different combinations of environmental driving conditions. However, given the apparent importance of late winter conditions in governing the magnitude of the spring $C$. glomerata bloom (Fig. 3), it is likely that given sufficiently long timescales sediment diatom archives should show a response to large-scale patterns of atmospheric 
variability affecting winter temperatures. These uncertainties may be resolved with additional analysis of diatom records, but will likely benefit from the application of independent proxies sensitive to changes in seasonal events such as the spring snowmelt pulse and ice phenology.

While considerable uncertainty remains in the mechanisms driving seasonal community development, we hypothesize that the sediment record is mainly controlled by subtle shifts in temperature, precipitation and discharge patterns, interacting with the timing of ice-break up, thermal stratification and lake over-turn. According to our interpretation, the build-up of a diatom bloom in boreal lakes is not only the result of the duration or intensity of the thermal stratification of the lake, ice cover duration or annual means, but is also related to the timing of different processes before spring and autumn lake over-turn. For example, runoff under the ice together with high light availability and stratified conditions seems to trigger a $C$. glomerata bloom, whereas high runoff leading to enhanced transport of solutes before autumn lake over-turn can induce an A. formosa bloom. According to our decadal-scale record, these two patterns related to spring and autumn blooms occur independently, which also partly explains the interannual and sub-annual variability.

Our study is limited to a single lake, and it is likely that specific seasonal patterns of diatom communities will vary in other systems. Indeed, variable seasonal patterns have been observed in some other boreal lakes (Boeff et al. 2016; Wiltse et al. 2016), although we note that the ice-covered period has been ignored in most previous studies, making conclusions about seasonality incomplete. Because the physical drivers examined in this study affect lakes throughout the boreal region, many of the general processes observed in this study should be able to inform interpretations of sediment diatom records in a wide variety of lakes, although specific drivers are likely to be more or less important in individual lakes. Given the apparent sensitivity of $C$. glomerata in particular to the timing of subtle early spring processes which are likely related to threshold effects (such as snowmelt and ice timing), superficially similar lakes may respond differently to changes in climate depending on their relationships to these thresholds. Future studies should examine the phenology of sedimenting diatoms in a variety of lake types throughout the full annual cycle, particularly along a gradient of winter severity and icecover duration.

\section{Conclusions}

A major challenge in incorporating ecological processes into the interpretation of sediment proxies are seasonal processes which underlie the most enormous changes which are difficult to identify statistically and yet give the clearest insight into environmental driver changes. Using a unique long-term record of highlyresolved diatom sedimentation, our study provides important empirical evidence that seasonal processes, particularly increasing winter air temperature and corresponding changes in runoff and ice-cover duration, have major implications for lake ecosystems. This study also highlights the importance of long-term datasets for the development of paleolimnological inferences, because reconstructions based on 1 or 2 years of monitoring data are unlikely to capture the full range of variability in both seasonal community development and sedimentation rates which are contained in the sediment archive. Although seasonality is likely to behave somewhat differently in other lakes, it is clear that processes related to seasonality and extreme seasonal events are more important for the interpretation of annual diatom sediment signals than annual average conditions such as mean annual temperature or precipitation, none of which showed significant relationships to the diatom community. Our study also suggests that the timing as well as the interconnection of processes occurring in the atmosphere, catchment, and in the lake itself may be more important than the actual intensity of major processes (e.g. spring flood, lake over-turn or date of ice breakup). These findings suggest that future research should focus on identifying the processes responsible for seasonal patterns using high frequency limnological observations including a range of potential drivers coupled with paleolimnological archives particularly during the transitional seasons in early spring and late autumn.

Acknowledgements We thank Marcus Klaus for help with Fig. 1 and Peter Isles for help with Figs. 6, 7 and 8 and helpful comments. This project was supported by a Grant no. (contract ID 90432301) from the Swedish Research Council Vetenskapsrådet. 
Open Access This article is distributed under the terms of the Creative Commons Attribution 4.0 International License (http:// creativecommons.org/licenses/by/4.0/), which permits unrestricted use, distribution, and reproduction in any medium, provided you give appropriate credit to the original author(s) and the source, provide a link to the Creative Commons license, and indicate if changes were made.

\section{References}

Amann B, Szidat S, Grosjean M (2015) A millennial-long record of warm season precipitation and flood frequency for the North-western Alps inferred from varved lake sediments: implications for the future. Quat Sci Rev 115:89-100

Anderson NJ, Renberg I, Segerstrom U (1995) Diatom production responses to the development of early agriculture in a boreal forest lake-catchment (Kassjön, Northern Sweden). J Ecol 83:809-822

Battarbee RW (2000) Palaeolimnological approaches to climate change, with special regard to the biological record. Quat Sci Rev 19:107-124

Battarbee RW, Kneen MJ (1982) The use of electronically counted microspheres in absolute diatom analysis. Limnol Oceanogr 271:184-189

Battarbee RW, Jones VJ, Flower RJ, Cameron NG, Bennion H, Carvalho L, Juggins S (2001) Diatoms. In: Last WM, Smol JP (eds) Tracking environmental change using lake sediments (Vol 3): terrestrial, algal and siliceous indicators. Kluwer Academic Publishers, Dordrecht, pp 155-202

Boeff KA, Strock KE, Saros JE (2016) Evaluating planktonic diatom response to climate change across three lakes with differing morphometry. J Paleolimnol 56:33-47

Bonk A, Tylmann W, Amann B, Enters D, Grosjean M (2015) Modern limnology and varve-formation processes in Lake Zabinskie, northeastern Poland: comprehensive process studies as a key to understand the sediment record. J Limnol 74:358-370

Bradbury JP (1988) Fossil diatoms and Neogene paleolimnology. Palaeogeogr Palaeoclimatol Palaeoecol 62:299-316

Brentrup JA, Williamson CE, Colom-Montero W, Eckert W, De Eyto E, Grossart HP, Huot Y, Isles PDF, Knoll LB, Leach TH, McBride CG, Pierson D, Pomati F, Read JS, Rose KC, Samal NR, Staehr PA, Winslow LA (2016) The potential of high-frequency profiling to assess vertical and seasonal patterns of phytoplankton dynamic in lakes: an extension of the Plankton Ecology Group (PEG) model. Inland Waters 6:565-580

Carlson RE, Simpson J (1996) A coordinator's guide to volunteer lake monitoring methods. North American Lake Management Society, Madison

Catalan J, Pla-Rabés S, Wolfe AP, Smol JP, Ruehland KM, Anderson JN, Kopáček J, Stuchlik E, Schmidt R, Konig KA, Camarero L, Flower RJ, Heiri O, Kamenik C, Korhola A, Leavitt PR, Psenner R, Renberg I (2013) Global change revealed by palaeolimnological records from remote lakes: a review. J Paleolimnol 49:513-535
Contosta AR, Adolph A, Burchsted D, Burakowski E, Green M, Guerra D, Albert M, Dibb J, Martin M, McDowell WH, Routhier M, Wake C, Whitaker R, Wollheim W (2017) A longer vernal window: the role of winter coldness and snowpack in driving spring transitions and lags. Glob Change Biol 23:1610-1625

Cortés A, MacIntyre S, Sadro S (2017) Flowpath and retention of snowmelt in an ice-covered arctic lake. Limnol Oceanogr. 62:2023-2044

DeNicola DM (1986) The representation of living diatom communities in deep-water sedimentary diatom assemblages in two Maine (U.S.A) lakes. In: Smol JP, Batterbee RW, Davis RB, Meriläinen J (eds) Diatoms and lake acidity. Dr. W. Junk Publisher, Dordrecht, pp 73-85

Gälman V, Rydberg J, Sjöstedt-de Luna S, Bindler R, Renberg I (2008) Carbon and nitrogen loss rates during aging of lake sediment: changes over 27 yeras studied in varved lake sediment. Limnol Oceanogr 53:1076-1082

Gälman V, Rydberg J, Shchukarev A, Sjöberg S, MartínezCortizas A, Bindler R, Renberg I (2009) The role of iron and sulphur in the visual appearance of lake sediment varves. J Paleolimnol 42:141-153

Hampton SE, Moore MV, Ozersky T, Stanley EH, Polashenski CM, Galloway AWE (2015) Heating up a cold subject: prospects for under-ice plankton research in lakes. J Plankton Res 37:277-284

Hampton SE, Galloway AWE, Powers SM, Ozersky T, Woo KH, Batt RD, Labou SG, O'Reilly CM, Sharma S, Lottig NR, Stanley EH, North RL, Stockwell JD, Adrian R, Weyhenmeyer GA, Arvola L, Baulch HM, Bertani I, Bowman LL, Carey CC, Catalan J, Colom-Montero W, Domine LM, Felip M, Granados I, Gries C, Grossart HP, Haberman J, Haldna M, Hayden B, Higgins SN, Jolley JC, Kahilainen KK, Kaup E, Kehoe MJ, MacIntyre S, Mackay AW, Mariash HL, McKay RM, Nixdorf B, Noges P, Noges T, Palmer M, Pierson DC, Post DM, Pruett MJ, Rautio M, Read JS, Roberts SL, Rucker J, Sadro S, Silow EA, Smith DE, Sterner RW, Swann GEA, Timofeyev MA, Toro M, Twiss MR, Vogt RJ, Watson SB, Whiteford EJ, Xenopoulos MA (2017) Ecology under lake ice. Ecol Lett 20:98-111

Haworth EY (1980) Comparison of continuous phytoplankton records with diatom stratigraphy in the recent sediments of Blelham Tarn, English Lake District. Limnol Oceanogr 25:1093-1103

Horvat C, Jones DR, Iams S, Schroeder D, Flocco D, Feltham D (2017) The frequency and extent of sub-ice phytoplankton blooms in the Arctic Ocean. Sci Adv 3:e1601191

Hutchinson GE (1967) A treatise on limnology. Volume II. Introduction to lake biology and the limnoplankton. Wiley, New York, p 1115

Jeppesen E, Kronvang B, Meerhoff M, Søndergaard M, Hansen KM, Andersen HE, Lauridsen TL, Liboriussen L, Beklioglu M, Özen A, Olesen JE (2009) Climate change effects on runoff, catchment phosphorus loading and lake ecological state, and potential adaptations. J Environ Qual 38:1930-1941

Juggins S (2013) Quantitative reconstructions in paleaeolimnology: new paradigm or sick science? Quat Sci Rev 64:20-32 
Kienel U, Kirillin G, Brademann B, Plessen B, Lampe R, Brauer A (2017) Effects of spring warming and mixing duration on diatom deposition in deep Tiefer See, NE Germany. J Paleolimnol 57:37-49

Kirilova EP, Heiri O, Bluszcz P, Zolitschka B, Lotter AF (2011) Climate-driven shifts in diatom assemblages recorded in annually laminated sediments of Sacrower See (NE Germany). Aquat Sci 73:201-210

Köster, D., Pienitz, R., Wolfe, B. B., Barry, S., Foster, D. R., Dixit, S. S. (2005) Paleolimnological assessment of human-induced impacts on Walden Pond (Massachusetts, USA) using diatoms and stable isotopes. Aquatic Ecosyst Health Manag 8(2):117-131

Krammer K, Lange-Bertalot H (1986-1991) Bacillariophyceae, vol 2. Gustav Fischer, Jena

Lotter AF, Bigler C (2000) Do diatoms in the Swiss Alps reflect the length of ice-cover? Aquat Sci 62:125-141

Lotter AF, Birks HJB, Hofmann W, Marchetto A (1997) Modern diatom, cladocera, chironomid, and chrysophyte cyst assemblages as quantitative indicators for the reconstruction of past environmental conditions in the Alps. I. Clim J Paleolimnol 18:395-420

Maier DB, Rydberg J, Bigler C, Renberg I (2013) Compaction of recent varved lake sediments. GFF 135:231-236

Ojala AEK, Bigler C, Weckström J (2014) Understanding varve formation processes from sediment trapping and limnological monitoring. PAGES Mag 22:8-9

Rautio M, Sovari S, Korhola A (2000) Diatom and crustacean zooplankton communities, their seasonal variability and representation in the sediments of subarctic lake Saanajärvi. J Limnol 59:81-96

Renberg I (1981) Improved methods for sampling, photographing and varve-counting of varved lake sediments. Boreas 10:255-258

Renberg I (1986) Photographic demonstration of the annual nature of a varve type common in N. Swedish lake sediments. Hydrobiologia 140:93-95

Renberg I, Hansson H (2010) Freeze corer No. 3 for lake sediments. J Paleolimnol 44:731-736

Renberg I, Korsman T, Birks JB (1993) Prehistoric increases in the $\mathrm{pH}$ of acid-sensitive Swedish lakes caused by land-use changes. Nature 362:824-827

Reynolds CS, Morison HR, Butterwick C (1982) The sedimentary flux of phytoplankton in the south basin of Windermere. Limnol Oceanogr 7:1162-1174

Reynolds CS, Huszar V, Kruk C, Naselli-Flores L, Melo S (2002) Towards a functional classification of the freshwater phytoplankton. J Plankton Res 24:417-428

Round FE, Crawford RM, Mann DG (1990) Diatoms: biology and morphology of the genera. Cambridge University Press, Cambridge

Ruehland K, Paterson AM, Smol JP (2008) Hemispheric-scale patterns of climate-related shifts in planktonic diatoms from North American and European lakes. Glob Change Biol 14:2740-2745

Ryves DB, Jewson DH, Sturm M, Battarbee RW, Flower RJ, Mackay AW, Granin NG (2003) Quantitative and qualitative relationships between planktonic diatom communities and diatom assemblages in sedimenting material and surface sediments in Lake Baikal, Siberia. Limnol Oceanogr 48:1643-1661
Salmi P, Salonen K (2016) Regular build-up of the spring phytoplankton maximum before ice-break in a boreal lake. Limnol Oceanogr 61:240-253

Salonen K, Lepparanta M, Viljanen M, Gulati RD (2009) Perspectives in winter limnology: closing the annual cycle of freezing lakes. Aquat Ecol 43:609-616

Saros JE, Anderson NJ (2015) The ecology of the planktonic diatom Cyclotella and its implications for global environmental change studies. Biol Rev 90:522-541

Saros JE, Michel TJ, Interlandi SJ, Wolfe AP (2005) Resource requirements of Asterionella formosa and Fragilaria crotonensis in oligotrophic alpine lakes: implications for recent phytoplankton community reorganizations. Can J Fish Aquat Sci 62:1681-1689

Saros JE, Stone JR, Pederson GT, Slemmons KEH, Spanbauer T, Schliep A, Cahl D, Williamson CE, Engstrom DR (2012) Climate-induced changes in lake ecosystem structure inferred from coupled neo- and paleoecological approaches. Ecology 93:2155-2164

Saros JE, Northington RM, Anderson DS, Anderson JN (2016) A whole-lake experiment confirms a small centric diatom species as an indicator of changing lake thermal structure. Limnol Oceanogr Lett 1:27-35

Simola H (1977) Diatom succession in the formation of annually laminated sediment in Lovojärvi, a small eutrophicated lake. Annales Botanici Societatis Yoologicae-Botanicae Fennicae "Vanamo" 14:143-148

Sivarajah B, Ruhland KM, Labaj AL, Paterson AM, Smol JP (2016) Why is the relative abundance of Asterionella formosa increasing in a Boreal Shield lake as nutrient levels decline? J Paleolimnol 55:357-367

Smol JP (1988) Paleoclimate proxy data from freshwater arctic diatoms. Verh Int Verein Theor Angew Limnol 23:837-844

Smol JP, Wolfe AP, Birks HJB, Douglas MSV, Jones VJ, Korhola A, Pienitz R, Ruhland K, Sorvari S, Antoniades D, Brooks SJ, Fallu MA, Hughes M, Keatley BE, Laing TE, Michelutti N, Nazarova L, Nyman M, Paterson AM, Perren B, Quinlan R, Rautio M, Saulnier-Talbot E, Siitoneni S, Solovieva N, Weckstrom J (2005) Climate-driven regime shifts in the biological communities of arctic lakes. Proc Natl Acad Sci USA 102:4397-4402

Sommer U, Gliwicz ZM, Lampert W, Ducan A (1986) The PEG-model of seasonal succession of planktonic event in fresh waters. Arch Hydrobiol 106:433-471

Sommer U, Adrian R, De Senerpond Domis L, Elser JJ, Gaedke U, Ibelings B, Jeppesen E, Lürling M, Molinero JC, Mooij WM, van Donk E, Winder M (2012) Beyond the plankton ecology group (PEG) model: mechanisms driving plankton succession. Annu Rev Ecol Evol Syst 43:429-448

Sorvari S, Korhola A, Thompson R (2002) Lake diatom response to recent Arctic warming in Finnish Lapland. Glob Change Biol 8:171-181

Ter Braak CJ, Smilauer P (2002) CANOCO reference manual and CanoDraw for Windows user's guide: software for canonical community ordination (version 4.5). Micorocomputer Power, Ithaca

Thackeray SJ, Jones ID, Maberly SC (2008) Long-term change in the phenology of spring phytoplankton: species-specific responses to nutrient enrichment and climatic change. J Ecol 96:523-535 
Vautard R, Gobiet A, Sobolowski S, Kjellström E, Stegehuis A, Watkiss P, Mendlik T, Landgren O, Nikulin G, Teichmann C, Kacob D (2014) The European climate under a $2{ }^{\circ} \mathrm{C}$ global warming. Environ Res Lett 9:034006

Weckström J, Korhola A, Blom T (1997) The relationship between diatoms and water temperature in thirty subarctic Fennoscandian lakes. Arct Alp Res 29:75-92

Wiltse B, Paterson AM, Findlay DL, Cumming BF (2016) Seasonal and decadal patterns in Discostella
(Bacillariophyceae) species from bi-weekly records of two boreal lakes (Experimental Lakes Are, Ontario, Canada). J Phycol 52:817-826

Zahrer JS, Dreibodt S, Brauer A (2013) Evidence of the North Atlantic Oscillation in varve composition and diatom assemblages from recent, annually laminated sediments of Lake Belau, northern Germany. J Paleolimnol 50:231-240 